\title{
Effects of food processing methods on migration of heavy metals to food
}

\author{
Joon-Goo Lee, Jeong-Yun Hwang, Hye-Eun Lee, Tae-Hun Kim, Jang-Duck Choi and Gil-Jin Gang* (10
}

\begin{abstract}
Heavy metals including Lead (Pb), Cadmium (Cd), Arsenic (As) and Aluminium (Al) were analysed in oilseeds, noodles, tea leaves and their processed or cooked products to study the effects of food processing methods on migration of heavy metals. The heavy metals were determined with ICP-MS and ICP-OES following microwave-assisted acid digestion. Heavy metals in oilseeds, noodles and teas were reduced by extracting oils, boiling noodles, and infusing teas. And the transfer of heavy metals into boiling water and infusion tea was increased as the boiling and infusion time is increased. Heavy metals in foods are water soluble and heavy metals in foods would be decreased when foods are processed or cooked with water. Furthermore, it is needed to determine the migration rates in other cooked foods and assess the risk of heavy metals with concentrations calculated by the migration rates.
\end{abstract}

Keywords: Heavy metal, Migration, Food processing, Oilseed, Noodle, Tea

\section{Introduction}

As societies are industrialized, a variety of contaminants cause serious environmental problems. Heavy metals are one of the main contaminants and they are ubiquitous in environment [1]. Heavy metals naturally exist on the earth's crust and they are significantly contaminated to environment by mining and processing metal ore. Human activity such as pesticide and herbicide applications also occur heavy metals in environment [2]. Heavy metals are accumulated in plants from environment such as soils and air, and they are transferred to animals through the food chains. People intake heavy metals by consuming foods which are contaminated with heavy metals [3].

Heavy metals can impact on human health. The U.S. Environmental protection Agency (EPA) has listed 20 hazardous substances in 2001, and As, $\mathrm{Pb}$, Mercury $(\mathrm{Hg})$ and $\mathrm{Cd}$ were ranked in the top of the list [4]. $\mathrm{Pb}$ is regarded as potential carcinogen and causes a number of serious health problems. Headache, irritability and

\footnotetext{
*Correspondence: tatabox96@naver.com

Food Contaminants Division, Department of Food Safety Evaluation, National Institute of Food and Drug Safety Evaluation, Ministry of Food and Drug Safety, Osong-eup, Cheongwon-gun, Chungcheongbuk-do 363-700, South Korea
}

various symptoms relating to the nervous system can be caused by short-term exposure to $\mathrm{Pb}$, and memory deterioration, prolonged reaction time and reduced ability to understand are some of symptoms of long-term exposure to $\mathrm{Pb}$ [5]. As is also considered as carcinogen being related to the lung, kidney, bladder and skin cancer. Hypertension and cardiovascular diseases are strongly related to arsenic exposure [6]. $\mathrm{Cd}$ is one of the hazard heavy metals. $\mathrm{Cd}$ is first reported as a reason of itai-itai disease from Japan in 1950s. Long-term exposure to high level of $\mathrm{Cd}$ causes skeletal damage and it has been classified as a human carcinogen by the IARC [7]. Aluminium (Al) is considered as a strong neurotoxicant, and irritation can be caused by inhalation or injection exposure to $\mathrm{Al}$ in animal experiments. Modest evidences for reproductive and bone toxicity exist following oral and injection exposure, respectively [8]. Several studies have shown that $\mathrm{Al}$ in drinking water and Alzheimer's disease have significant relations, even though the relation is still on debate [9].

A number of studies have determined heavy metals in different food categories. EFSA published the scientific opinions about the contaminations of $\mathrm{Pb}, \mathrm{Cd}, \mathrm{Al}$ and As in food [10-12]. Especially, oilseeds of plants easily uptake heavy metals from soil and accumulate them, even though different plants have different distributional 
character of heavy metals to organs such as roots, stems, leaves, fruit shell and seeds. Chizzola [13] ascertained that seeds of sunflowers contained high level of $\mathrm{Cd}$, while some studies show that roots and leaves accumulate more heavy metals than seeds [14, 15]. However, edible oils do not contain as high level of heavy metals as seeds [16]. Tea also have heavy metals in their leaves. However, levels of heavy metals in tea infusion were not as high as those in tea leaves [17]. Heavy metal contents in food would be changed during cooking or producing processes. Therefore, in this study, we analyzed the levels of $\mathrm{Pb}, \mathrm{Cd}$, As and $\mathrm{Al}$ in foods and their cooked and processed foods to determine migration and residual rates of $\mathrm{Pb}, \mathrm{Cd}, \mathrm{As}$ and $\mathrm{Al}$ in food according to cooking and processing methods on different conditions. We chose oilseeds, noodles and teas as representative foods to compare the differences of extracting heavy metals with oil and water. There are some research to compare the heavy metal contents in oilseeds and their oils. But they did not consider different extracting methods such as pressing extraction and solvent extraction and different kinds of oilseeds [16]. Teas also have been studied to compare heavy metal contents in teas and their infusions. However, they analyzed only $\mathrm{Pb}$ and $\mathrm{Cd}$, and they did not compare the levels of heavy metals according to infusion time $[17,18]$. And there are no studies to compare heavy metal contents before and after boiling noodles. We extracted oils from seeds, boiled noodles and infused teas by different methods. And the migration rates occurred based on water solubility of heavy metals were estimated by extracting them with oil and water. Especially, we consider the two cases in which we intake water or remove water after extracting heavy metals with water by analyzing noodles and teas.

\section{Materials and methods}

\section{Chemicals and materials}

The standards of $\mathrm{Pb}, \mathrm{Cd}$, As and $\mathrm{Al}$ were purchased from Merck (Darmstadt, Germany) and nitric acid and hydrogen peroxide were of electronic grade from Wako (Osaka, Japan). $n$-hexane from Merck (Darmstadt, Germany) were prepared. The standards of $\mathrm{Pb}, \mathrm{Cd}$ and $\mathrm{As}$ of $1000 \mathrm{mg} / \mathrm{kg}$ were diluted to working solutions of $100 \mu \mathrm{g} /$ $\mathrm{kg}$ with $\mathrm{HNO}_{3}(3 \%)$. The standard of $\mathrm{Al}$ was prepared at the level of $1000 \mathrm{mg} / \mathrm{kg}$, and it was diluted to working solution of $100 \mathrm{mg} / \mathrm{kg}$ with $\mathrm{HNO}_{3}$ (3\%). Water purified by a Milli-Q System (Millipore, Bedford, MA, USA) was used and edible oil, peach leaves, spinach leaves and fortified ginseng for certified reference material (CRM) were purchased from FAPAS (TET009RM, York, UK), NIST (1547, Gaithersburg, MD), NIST (1570a, Gaithersburg, $\mathrm{MD}$ ) and KRISS (Daejun, Korea). Edible oil contained Pb of $0.332 \mathrm{mg} / \mathrm{kg}$, peach leaves contained $\mathrm{Pb}$ of $0.869 \mathrm{mg} /$ $\mathrm{kg}$, Cd of $0.0261 \mathrm{mg} / \mathrm{kg}$ and $\mathrm{Al}$ of $248.0 \mathrm{mg} / \mathrm{kg}$, spinach leaves contained $\mathrm{Cd}$ of $2.876 \mathrm{mg} / \mathrm{kg}$, As of 0.068 and $\mathrm{Al}$ of $310.0 \mathrm{mg} / \mathrm{kg}$ and fortified ginseng contained $\mathrm{Pb}$ of $10.749 \mathrm{mg} / \mathrm{kg}$ and Cd of $1.178 \mathrm{mg} / \mathrm{kg}$. Argon gas was of spectral purity of $99.9998 \%$.

\section{Samples}

Sesame seeds, perilla seeds and flaxseeds were chosen for comparing the levels of heavy metals in seeds and oils and 3 samples of each seed were purchased at Korean offline markets. Sesame oil and perilla oil are the most consumed oils in Korea according to the Korea National Health and Nutrition Examination survey (KNHANES) [19] and flaxseed oil can be highly contaminated by $\mathrm{Cd}$ [20]. Sesame and perilla were originated from Korea and flaxseeds were imported from Canada. And flour noodle and sweet potato glass noodle were selected for comparing the heavy metals contents before and after boiling. Flour noodles and glass noodles are highly consumed in Korea by KNHANES [19]. Flour noodle was made from Korean wheat flour, and glass noodle is made from sweet potato starch in Korea, which is widely used in Asian foods. 3 flour noodles and 3 glass noodle were purchased at Korean offline markets. For infusing teas, black, green and Solomon's seal tea were selected. Black, green and Solomon's seal tea would be contaminated with heavy metals because black and green tea are made of the leaves of the plant Camellia sinensis and solomon's seal tea is made of the roots of plant, Polygonatum odoratum var. pluriflorum Ohwi. Leaves and roots accumulated heavy metals. Black teas were made in Sri Lanka and green and Solomon's teas were made in Korea. 3 black teas and 3 green teas and 3 Solomon's teas were purchased at Korean offline markets.

\section{Cooking and processing methods Oil extraction}

The most widely used methods for extractions of edible oils are mechanical pressing, solvent and supercriticalfluid extraction [21]. The mechanical pressing technique has been the most used method with relatively low costs. However, its efficiency is very low comparing to other two methods [22]. Solvent extraction has been used recently in the last century. It has advantage of extraction efficiency (>99 wt\%), while its quality is reduced because of the solvent recovery process [22, 23]. Supercriticalfluid extraction is way to extract oil with supercritical fluids which have gas-like diffusivities but liquid-like densities. Carbon dioxide $\left(\mathrm{CO}_{2}\right)$ is the most frequently used for extracting edible oils [24]. We had oils extracted by these three methods in oil-extracting companies. 


\section{Pressing extraction}

Compression oil extractor, P-16(S) (Poong-jin, Busan, Korea) was used for extracting oil. Flaxseeds of $4840 \mathrm{~g}$, sesame of $5000 \mathrm{~g}$ and perilla of $5000 \mathrm{~g}$ were fried before pressing at $160{ }^{\circ} \mathrm{C}$ for $10 \mathrm{~min}, 180{ }^{\circ} \mathrm{C}$ for $20 \mathrm{~min}$, and $160{ }^{\circ} \mathrm{C}$ for $10 \mathrm{~min}$. And then, fried seeds were pressed by $200 \times 10^{5} \mathrm{~Pa}$ at $70{ }^{\circ} \mathrm{C}$ for $15 \mathrm{~min}$. Flaxseed oil of $1670 \mathrm{~g}$, sesame oil of $1530 \mathrm{~g}$ and perilla oil of $1528 \mathrm{~g}$ were extracted from seeds.

\section{Solvent extraction}

$\mathrm{n}$-Hexane was used for solvent extraction with solvent extractor, E-816 HE (Buchi Labortechnik AG, Flawil, Switzerland). Seeds were extracted for $100 \mathrm{~min}$ at $165{ }^{\circ} \mathrm{C}$ followed by being evaporated for $20 \mathrm{~min}$ at $150{ }^{\circ} \mathrm{C}$. It was dried for $10 \mathrm{~min}$ at $150{ }^{\circ} \mathrm{C}$. Flaxseeds of $20.32 \mathrm{~g}$, sesame of $11.81 \mathrm{~g}$ and perilla of $11.78 \mathrm{~g}$ were extracted to oil of $5.72 \mathrm{~g}, 3.42 \mathrm{~g}$ and $3.14 \mathrm{~g}$, respectively.

\section{Supercritical $\mathrm{CO}_{2}$ extraction}

Supercritical extraction was performed with a supercritical-fluid extractor, L-1000 Bar-Pilot Plant (Natex, Ternitz, Austria) equipped with Mass flow meter, independently controlled heating circuits for the extractor and the separators, $\mathrm{CO}_{2}$ recycling system including unit and computerized control system for $240 \mathrm{~min}$. Extractor and separator run at $400 \times 10^{5} \mathrm{~Pa}$ at $50{ }^{\circ} \mathrm{C}$ and $40 \times 10^{5} \mathrm{~Pa}$ at $40{ }^{\circ} \mathrm{C}$ and $\mathrm{CO}_{2}$ run at a flow rate of $60 \mathrm{~mL} / \mathrm{min}$. The extracts were collected in a vessel attached to a refrigerated bath at $-2{ }^{\circ} \mathrm{C}$. Flaxseed oils of $95.7 \mathrm{~g}$, sesame oils of $74.3 \mathrm{~g}$ and perilla oils of $75.3 \mathrm{~g}$ were extracted from flaxseeds of $250 \mathrm{~g}$, sesame of $200 \mathrm{~g}$ and perilla of $200 \mathrm{~g}$, respectively.

\section{Noodle boiling}

The noodles of $50 \mathrm{~g}$ were boiled in water of $1 \mathrm{~L}$ at $100{ }^{\circ} \mathrm{C}$ for 3, 5, and $10 \mathrm{~min}$. Noodles were stirred with chopsticks during boiling, and water was removed from noodles after boiling. Figure 1 shows the boiling procedure.

\section{Tea infusion}

The teas of $1.2 \mathrm{~g}$ were put in tea bags which were made from polyethylene and polypropylene, and tea bags were infused in water of $150 \mathrm{~mL}$ at $98{ }^{\circ} \mathrm{C}$ for 2,10 , and $30 \mathrm{~min}$. Tea bags were separated from the tea infusion and water was removed from tea bags after infusing. Figure 1 shows the infusing procedure.

\section{Microwave-assisted acid digestion}

Following homogenization of samples, $0.20 \mathrm{~g}$ of samples were weighed in polytetrafluoroethylene (PTFE) flasks of $20 \mathrm{~mL}$, and the flasks were kept for pre-digestion at
$80{ }^{\circ} \mathrm{C}$ for $15 \mathrm{~min}$ and at $140{ }^{\circ} \mathrm{C}$ for 25 min with $\mathrm{HNO} 3$ $(60 \%)$ of $10 \mathrm{~mL}$ and $\mathrm{H} 2 \mathrm{O} 2(30 \%)$ of $1 \mathrm{~mL}$. And then, the flasks were placed in a microwave oven, Easy Control-280 (Milestone, Sorisole, Italy) for digestion by increasing temperature from 0 to $80{ }^{\circ} \mathrm{C}$ for $5 \mathrm{~min}$, and then digestion temperature were decreased to $50{ }^{\circ} \mathrm{C}$ for $3 \mathrm{~min}$. The flasks were finally digested at $180^{\circ} \mathrm{C}$ for $20 \mathrm{~min}$ following being heated to $180{ }^{\circ} \mathrm{C}$ for $15 \mathrm{~min}$. After cooling the flasks, distilled water was added to wash the residue in the flask up to $25 \mathrm{~g}$.

\section{Determination of heavy metals with ICP-MS and ICP-OES}

$\mathrm{Pb}, \mathrm{Cd}$ and As were determined with inductively-coupled plasma (ICP) with mass spectrometry (MS), Dionex ICS$5000+$ SP (Thermo Fisher, Waltham, MA, USA). It was operated with RF power of $1.3 \mathrm{~kW}$, argon gas flow rates of $15 \mathrm{~mL} / \mathrm{min}$ for plasma, $0.9 \mathrm{~L} / \mathrm{min}$ for auxiliary and $1-1.1 \mathrm{~L} / \mathrm{min}$ for nebulizer. The quadrupole mass analyser ionized $\mathrm{Pb}, \mathrm{Cd}$ and $\mathrm{As}$ in the single ion monitoring mode to analytical masses of $\mathrm{m} / \mathrm{z} 208, \mathrm{~m} / \mathrm{z} 111$ and $\mathrm{m} / \mathrm{z} 75$, respectively.

A inductively-coupled plasma (ICP) optical emission spectrometer (OES), Optima 8300 (Perkinelmer, Waltham, MA, USA) was used for determining Al. It was equipped with Mirawire nebulizer, BPC3-50R6 (Elemental Scientific, Omaha, NE), cychronic spray chamber and quarts torch, and it was operated with RF power of $1.50 \mathrm{~kW}$, argon gas flow rates of $10.0 \mathrm{~L} / \mathrm{min}$ for coolant, $0.2 \mathrm{~L} / \mathrm{min}$ for auxiliary and $0.7 \mathrm{~mL} / \mathrm{min}$ for nebulizer and wavelength of $396.153 \mathrm{~nm}$. Samples were taken at the flow rate of $1.0 \mathrm{~mL} / \mathrm{min}$.

\section{Method validation}

The analytical method was verified for quality control with performance parameters: Limit of Detection (LOD), Limit of Quantification (LOQ), linearity of calibration curves, and accuracy including recovery and precision. LOD and LOQ were calculated by multiplying standard deviation by 3 and 10, and a standard deviation was derived from measurements of 10 blank samples. Calibration curves for heavy metals were obtained by computing regression equations with plots pointed by peak areas against concentrations in a range of 0.01 to $20 \mu \mathrm{g} /$ $\mathrm{kg}$ for $\mathrm{Pb}, \mathrm{Cd}$ and $\mathrm{As}$ and 0.1 to $30 \mathrm{mg} / \mathrm{kg}$ at different 3 days. The linearity of calibration curve was evaluated by the coefficient of correlation of regression equation. The accuracy was measured by analyzing CRM of edible oil, Ginseng powder and peach leaves three times a day. The recoveries were calculated by comparing the concentrations of CRMs and analyzed concentrations. The repeatability was obtained by calculating standard deviations of results of inter-day tests. 
(a)

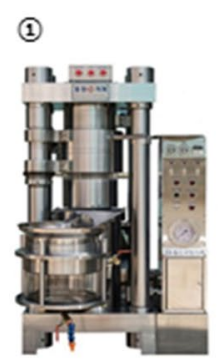

(2)

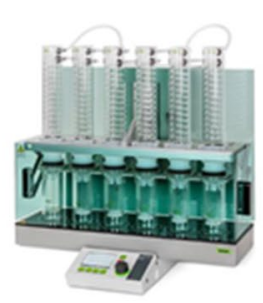

(3)

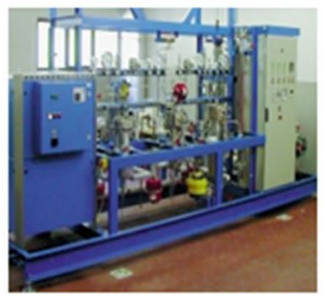

(1) Pressing extraction (2) Solvent extraction (3) Supercritical $\mathrm{CO}_{2}$ extraction
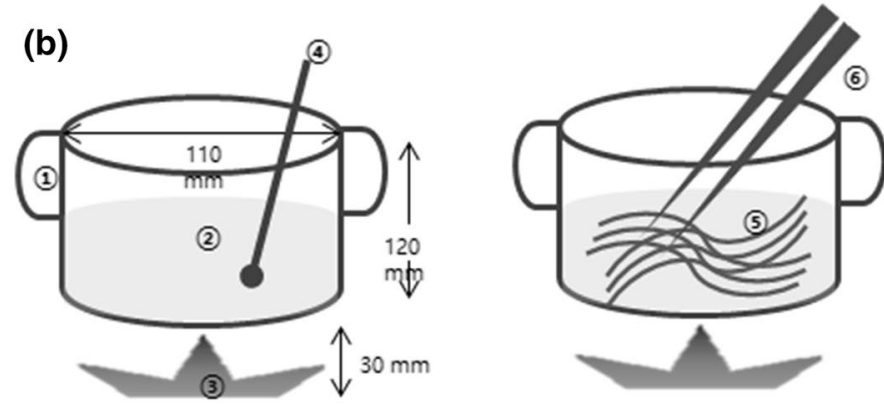

(1) Pot

(2) Water $(1,000 \mathrm{ml})$

(3) Heat source

(4) Thermometer

$\left(100^{\circ} \mathrm{C}\right)$

(5) Noodle (50 g)

(6) Chopsticks

(c)
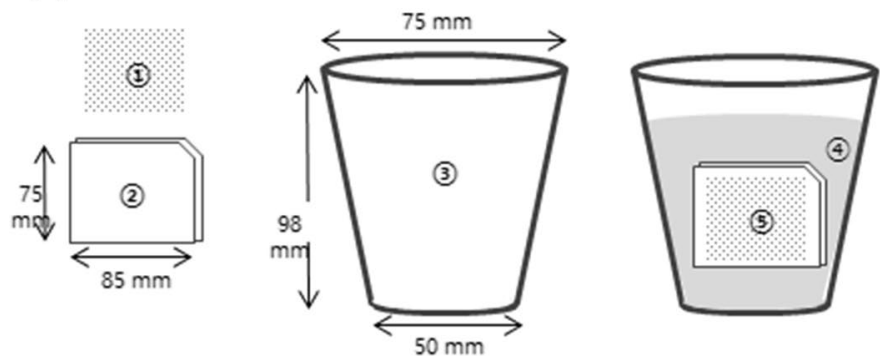

(1) Raw material (1.2 g) (2) Tea bag (Polyethylene-polyprophylene)

(3) Paper cup

(4) Water $\left(98^{\circ} \mathrm{C}, 150 \mathrm{ml}\right)$

(5) Raw material in tea bag

Fig. 1 Designs of cooking methods to study the effects on transfer of heavy metals: a oil extraction, $\mathbf{b}$ noodle boiling and $\mathbf{c}$ tea infusion

Every sample batch was analyzed with double distilled deionized water for checking the instruments' conditions and CRM was included in sample batch once a month. Instruments were calibrated and maintained every 3 months by instrument maintenance teams.

\section{Statistical analysis}

Data was calculated as mean with standard deviation of triplicate measurements. To assess significant differences in levels of heavy metals in the different procedures, the student's t-tests were conducted by using Microsoft Office Excel 2007 (Microsoft Corporation, Redmond, WA, USA). Migration rates and residual rates were calculated by the amount of heavy metals because the concentrations of heavy metals were changed by the amount of food and water and they did not show the exact the migration and residual rates of heavy metals. Extracting, boiling and infusion were carried out three times for each food.

\section{Results and discussion Method validation}

Table 1 shows the performance parameters for verifying the analytical methods. The LODs for $\mathrm{Pb}, \mathrm{Cd}$, As and $\mathrm{Al}$ were ranged from 0.010 to $0.859 \mu \mathrm{g} / \mathrm{kg}$ and the LOQs were from 0.035 to $2.863 \mu \mathrm{g} / \mathrm{kg}$. The linear regression analysis ensured that the calibration curves had good linear relationships between peak areas and concentrations with regression coefficients of 0.999 . The relative recoveries of $\mathrm{Pb}, \mathrm{Cd}$, As and $\mathrm{Al}$ from CRM were from 71.5 to $107.5 \%$ and relative standard deviations for repeatability were 0.84 to $18.55 \%$. values were 
Table 1 Linear equation, limits of detection and quantitation (LOD and LOQ), relative recovery, and precision obtained for heavy metals

\begin{tabular}{|c|c|c|c|c|c|c|c|}
\hline Heavy metals & Linear equation & $\begin{array}{l}\text { Regression } \\
\text { coefficient }\end{array}$ & Matrix & $\operatorname{LOD}(\mu \mathrm{g} / \mathrm{kg})$ & LOQ $(\mu \mathrm{g} / \mathrm{kg})$ & $\begin{array}{l}\text { Relative } \\
\text { recovery (\%) }\end{array}$ & $\mathrm{RSD}^{\mathrm{r}}(\%)$ \\
\hline \multirow[t]{3}{*}{$\mathrm{Pb}$} & $y=1.0032 x-0.0465$ & 0.999 & Ginseng powder & 0.859 & 2.863 & 89.919 & 2.963 \\
\hline & & & Edible oil & 0.011 & 0.036 & 78.071 & 1.385 \\
\hline & & & Peach leaves & 0.122 & 0.405 & 81.452 & 7.723 \\
\hline \multirow[t]{3}{*}{$\mathrm{Cd}$} & $y=1.0008 x-0.0121$ & 0.999 & Spinach leaves & 0.123 & 0.410 & 71.495 & 1.995 \\
\hline & & & Ginseng powder & 0.023 & 0.076 & 77.300 & 0.838 \\
\hline & & & Peach leaves & 0.012 & 0.040 & 83.250 & 18.552 \\
\hline As & $y=0.9988 x+0.017$ & 0.999 & Spinach leaves & 0.010 & 0.035 & 77.644 & 6.580 \\
\hline \multirow[t]{2}{*}{$\mathrm{Al}$} & $y=51,332.1 x+4246.1$ & 0.999 & Spinach leaves & 0.047 & 0.158 & 101.306 & 5.016 \\
\hline & & & Peach leaves & 0.016 & 0.054 & 107.450 & 2.027 \\
\hline
\end{tabular}

$R S D^{r}$ repeatability in single-laboratory

acceptable according to criteria recommended by the AOAC [25].

\section{Change of heavy metal contents by extracting oils}

The mean amounts of $\mathrm{Pb}$ in seed were $0.758 \pm 0.152 \mu \mathrm{g}$ to $936.000 \pm 97.083 \mu \mathrm{g}$. And contents of Cd were from $0.133 \pm 0.038$ to $2610.251 \pm 429.354 \mu \mathrm{g}$. Seeds were contaminated from $0.612 \pm 0.086$ to $678.788 \pm 33.686 \mu \mathrm{g}$ by As and $0.498 \pm 0.003$ to $1023.546 \pm 187.529 \mathrm{mg}$ by Al (Table 2). Seeds contain wide levels of heavy metals, and $\mathrm{Al}$ was highly detected than other heavy metals such as $\mathrm{Pb}, \mathrm{Cd}$ and As. Different kinds of seeds contain different levels of heavy metals. This is because different plants have different proper to uptake heavy metals [2]. However, the effect of soil contamination could not be estimated without information about the area where the plants grew up. Flaxseeds contain higher level of $\mathrm{Cd}$ comparing to $\mathrm{Pb}$ and As while sesame contains higher level of As and Perillas contain higher level of Pb. Flaxseeds have some $\mathrm{Cd}$ binding proteins and contains high level of $\mathrm{Cd}$ [26], and sesame is a strong accumulator of arsenic [27].

Heavy metal contents in extracted oils were much less than those in seeds. The mean amounts of $\mathrm{Pb}$ were from $0.019 \pm 0.016$ to $36.010 \pm 53.832 \mu \mathrm{g}$, and contents of $\mathrm{Cd}$ were from ND to $70.030 \pm 103.731 \mu \mathrm{g}$. And oils were contaminated from $0.011 \pm 0.013$ to $15.185 \pm 8.418 \mu \mathrm{g}$ by As and $0.029 \pm 0.008$ to $29.814 \pm 3.463 \mathrm{mg}$ by Al (Table 2). Levels of $\mathrm{Pb}$ and $\mathrm{As}$ in this study were similar with other studies, in which $\mathrm{Pb}$ of 0.056 to $0.072 \mu \mathrm{g}$ and As of 0.060 to $0.079 \mu \mathrm{g}$ in sesame oil of $4 \mathrm{~g}$ were determined in China [28] and Pb of 0.192 (LB) and 0.288 (UB) $\mu \mathrm{g}$ in vegetable fats and oils of $4 \mathrm{~g}$ were detected in EU [29]. Vegetable fats and oils of $4 \mathrm{~g}$ were containing As of 0.025 (LB) and 0.135 (UB) $\mu \mathrm{g}$ in EU [11] and Cd of ND to $0.416 \mu \mathrm{g}$ in fats of vegetable and animal of $4 \mathrm{~g}$ [12].
All heavy metals were significantly decreased $(p<0.05)$ in oils by extracting them from seeds (Fig. 2). Pb, Cd, As and $\mathrm{Al}$ in seeds were transferred to oils by 1.1 to $32.5 \%$, 0 to $27.3 \%, 0.9$ to $20.0 \%$ and 1.7 to $23.9 \%$, respectively. Heavy metals were transferred from seeds to oils less than $10 \%$ by pressing and solvent extractions other than $\mathrm{Cd}$ in Perilla oils. This would be because heavy metals combine to some minerals and dissolves easily in water. They are up-taken by plants through water. Therefore, heavy metals in seeds are very water-soluble [30]. The transfer rates of heavy metals were up to $30 \%$ in supercritical-fluid extraction. Supercritical-fluid extraction extracts more heavy metals rather than other extraction processes. This would be because supercritical-fluid extraction is more effective in extracting components of seeds rather than solvent and pressing extractions. Omega-6-fatty acid and mega-3-fatty acid were more extracted by supercriticalfluid extraction rather than by other extraction processes [21,31]. Even though supercritical-fluids procedure is one of the most efficient extraction processes in food products [15], it needs to be improved on selectivity not to extract hazardous components such as heavy metals.

\section{Change of heavy metal contents by boiling noodles}

Flour noodles of $50 \mathrm{~g}$ were containing $\mathrm{Pb}$ of $0.820 \pm 0.399 \mu \mathrm{g}, \quad \mathrm{Cd}$ of $0.714 \pm 0.042 \mu \mathrm{g}$, As of $0.055 \pm 0.023 \mu \mathrm{g}$ and $\mathrm{Al}$ of $0.768 \pm 0.032 \mathrm{mg}$. And glass noodles of $50 \mathrm{~g}$ were contaminated by $\mathrm{Pb}$ of $0.634 \pm 0.150 \mu \mathrm{g}$, As of $0.086 \pm 0.022 \mu \mathrm{g}$ and $\mathrm{Al}$ of $0.981 \pm 0.005 \mathrm{mg}$. Cd were not detected in glass noodles (Table 2). Noodles including glass noodles were made from grains or vegetables. Grains and vegetables also uptake heavy metals from environment and accumulate them [2]. Heavy metals would be transferred to noodles from raw materials. Especially, $\mathrm{Al}$ is allowed to add to noodles as a leavening agent, acidic sodium aluminum 
Table 2 Contents of heavy metals in oilseeds and their extracted oils, noodles and their boiled noodles and teas and their infusions

\begin{tabular}{|c|c|c|c|c|c|c|}
\hline \multirow[t]{2}{*}{ Method } & \multirow[t]{2}{*}{ Food } & \multirow[t]{2}{*}{ Status/time } & \multicolumn{4}{|l|}{ Heavy metal } \\
\hline & & & $\mathrm{Pb}(\mu \mathrm{g})$ & $\mathrm{Cd}(\mu \mathrm{g})$ & As $(\mu \mathrm{g})$ & $\mathrm{Al}(\mathrm{mg})$ \\
\hline \multicolumn{7}{|l|}{ Oil extraction } \\
\hline \multirow[t]{6}{*}{ Pressing } & Flaxseed & Seed & $373.624 \pm 142.869^{\mathrm{a}}$ & $2610.251 \pm 429.354^{\mathrm{a}}$ & $557.181 \pm 259.443^{a}$ & $118.702 \pm 0.705^{\mathrm{a}}$ \\
\hline & & Oil & $25.652 \pm 36.963^{b}$ & $70.030 \pm 103.731^{b}$ & $3.102 \pm 1.036^{b}$ & $29.8144 \pm 3.463^{b}$ \\
\hline & Sesame & Seed & $321.154 \pm 64.165^{\mathrm{a}}$ & $448.447 \pm 44.324^{a}$ & $678.788 \pm 33.686^{a}$ & $849.674 \pm 116.487^{a}$ \\
\hline & & Oil & $36.010 \pm 53.832^{b}$ & $0.000 \pm 0.000^{b}$ & $15.185 \pm 8.418^{b}$ & $15.974 \pm 14.484^{b}$ \\
\hline & Perilla & Seed & $936.000 \pm 97.083^{\mathrm{a}}$ & $56.446 \pm 16.043^{\mathrm{a}}$ & $259.843 \pm 36.355^{\mathrm{a}}$ & $1023.546 \pm 187.529^{a}$ \\
\hline & & Oil & $35.519 \pm 34.428^{b}$ & $8.642 \pm 14.705^{b}$ & $14.109 \pm 3.926^{b}$ & $25.546 \pm 10.514^{b}$ \\
\hline \multirow[t]{6}{*}{ Solvent } & Flaxseed & Seed & $1.569 \pm 0.600^{\mathrm{a}}$ & $10.961 \pm 1.803^{\mathrm{a}}$ & $2.340 \pm 1.089^{a}$ & $0.498 \pm 0.003^{\mathrm{a}}$ \\
\hline & & Oil & $0.168 \pm 0.063^{b}$ & $1.059 \pm 1.314^{b}$ & $0.148 \pm 0.126^{b}$ & $0.029 \pm 0.008^{b}$ \\
\hline & Sesame & Seed & $0.758 \pm 0.152^{\mathrm{a}}$ & $1.059 \pm 0.105^{\mathrm{a}}$ & $1.603 \pm 0.080^{\mathrm{a}}$ & $2.007 \pm 0.275^{\mathrm{a}}$ \\
\hline & & Oil & $0.025 \pm 0.009^{b}$ & $0.000 \pm 0.000^{b}$ & $0.037 \pm 0.052^{b}$ & $0.047 \pm 0.034^{b}$ \\
\hline & Perilla & Seed & $2.206 \pm 0.229^{a}$ & $0.133 \pm 0.038^{\mathrm{a}}$ & $0.612 \pm 0.086^{\mathrm{a}}$ & $2.412 \pm 0.442^{\mathrm{a}}$ \\
\hline & & Oil & $0.019 \pm 0.016^{b}$ & $0.000 \pm 0.000^{b}$ & $0.011 \pm 0.013^{b}$ & $0.041 \pm 0.033^{b}$ \\
\hline \multirow[t]{6}{*}{ Supercritical-fluid } & Flaxseed & Seed & $19.299 \pm 7.380^{\mathrm{a}}$ & $134.827 \pm 22.177^{\mathrm{a}}$ & $28.780 \pm 13.401^{\mathrm{a}}$ & $6.131 \pm 0.036^{\mathrm{a}}$ \\
\hline & & Oil & $6.249 \pm 3.989^{b}$ & $8.300 \pm 3.321^{b}$ & $5.716 \pm 4.432^{b}$ & $0.175 \pm 0.113^{b}$ \\
\hline & Sesame & Seed & $12.846 \pm 2.567^{\mathrm{a}}$ & $17.938 \pm 1.773^{\mathrm{a}}$ & $27.152 \pm 1.347^{\mathrm{a}}$ & $33.987 \pm 4.659^{a}$ \\
\hline & & Oil & $0.140 \pm 0.221^{b}$ & $0.025 \pm 0.031^{b}$ & $0.430 \pm 0.086^{b}$ & $1.232 \pm 0.728^{b}$ \\
\hline & Perilla & Seed & $37.440 \pm 3.883^{\mathrm{a}}$ & $2.259 \pm 0.642^{\mathrm{a}}$ & $10.394 \pm 1.454^{\mathrm{a}}$ & $40.942 \pm 7.501^{\mathrm{a}}$ \\
\hline & & Oil & $4.183 \pm 3.778^{b}$ & $0.574 \pm 0.993^{b}$ & $0.805 \pm 0.330^{b}$ & $3.031 \pm 1.668^{b}$ \\
\hline \multirow[t]{8}{*}{ Boiling noodle } & Flour noodles & Control & $0.820 \pm 0.399$ & $0.714 \pm 0.042$ & $0.055 \pm 0.023$ & $0.768 \pm 0.032$ \\
\hline & & $3 \min$ & $0.354 \pm 0.250^{\mathrm{a}}$ & $0.173 \pm 0.122^{\mathrm{a}}$ & $0.000 \pm 0.000^{\mathrm{a}}$ & $0.257 \pm 0.008^{a}$ \\
\hline & & $5 \mathrm{~min}$ & $0.298 \pm 0.190^{\mathrm{a}}$ & $0.103 \pm 0.076^{\mathrm{a}}$ & $0.002 \pm 0.005^{\mathrm{a}}$ & $0.217 \pm 0.017^{b}$ \\
\hline & & $10 \mathrm{~min}$ & $0.251 \pm 0.126^{a}$ & $0.049 \pm 0.009^{a}$ & $0.011 \pm 0.018^{\mathrm{a}}$ & $0.203 \pm 0.002^{b}$ \\
\hline & Glass noodles & Control & $0.634 \pm 0.150$ & $0.000 \pm 0.000$ & $0.086 \pm 0.022$ & $0.981 \pm 0.005$ \\
\hline & & $3 \min$ & $0.359 \pm 0.132^{\mathrm{a}}$ & $0.000 \pm 0.001$ & $0.002 \pm 0.004^{\mathrm{a}}$ & $0.556 \pm 0.004^{\mathrm{a}}$ \\
\hline & & $5 \mathrm{~min}$ & $0.289 \pm 0.177^{a}$ & $0.000 \pm 0.000$ & $0.000 \pm 0.000^{\mathrm{a}}$ & $0.476 \pm 0.004^{b}$ \\
\hline & & $10 \mathrm{~min}$ & $0.191 \pm 0.036^{\mathrm{a}}$ & $0.000 \pm 0.000$ & $0.000 \pm 0.000^{\mathrm{a}}$ & $0.347 \pm 0.002^{c}$ \\
\hline \multirow[t]{12}{*}{ Infusing tea } & Green tea & Control & $0.219 \pm 0.008$ & $0.017 \pm 0.002$ & $0.073 \pm 0.015$ & $4.694 \pm 0.119$ \\
\hline & & $2 \min$ & $0.047 \pm 0.002^{\mathrm{a}}$ & $0.003 \pm 0.001^{\mathrm{a}}$ & $0.003 \pm 0.005^{\mathrm{a}}$ & $1.441 \pm 0.119^{\mathrm{a}}$ \\
\hline & & $10 \mathrm{~min}$ & $0.056 \pm 0.001^{b}$ & $0.003 \pm 0.003^{\mathrm{a}}$ & $0.006 \pm 0.002^{b}$ & $1.957 \pm 0.147^{b}$ \\
\hline & & $30 \mathrm{~min}$ & $0.065 \pm 0.002^{c}$ & $0.005 \pm 0.003^{\mathrm{a}}$ & $0.007 \pm 0.005^{b}$ & $2.462 \pm 0.098^{c}$ \\
\hline & Black tea & Control & $0.657 \pm 0.061$ & $0.011 \pm 0.001$ & $0.049 \pm 0.005$ & $1.039 \pm 0.039$ \\
\hline & & $2 \min$ & $0.330 \pm 0.081^{a}$ & $0.003 \pm 0.003^{\mathrm{a}}$ & $0.023 \pm 0.009^{\mathrm{a}}$ & $0.663 \pm 0.128^{a}$ \\
\hline & & $10 \mathrm{~min}$ & $0.429 \pm 0.138^{\mathrm{a}}$ & $0.006 \pm 0.006^{b}$ & $0.038 \pm 0.017^{\mathrm{a}}$ & $0.786 \pm 0.126^{a}$ \\
\hline & & $30 \mathrm{~min}$ & $0.558 \pm 0.194^{b}$ & $0.010 \pm 0.009^{b}$ & $0.049 \pm 0.019^{b}$ & $0.864 \pm 0.054^{b}$ \\
\hline & Solomon's seal tea & Control & $0.474 \pm 0.163$ & $0.054 \pm 0.008$ & $0.053 \pm 0.009$ & $0.428 \pm 0.026$ \\
\hline & & $2 \min$ & $0.086 \pm 0.017^{a}$ & $0.004 \pm 0.004^{a}$ & $0.002 \pm 0.003^{\mathrm{a}}$ & $0.214 \pm 0.022^{\mathrm{a}}$ \\
\hline & & $10 \mathrm{~min}$ & $0.175 \pm 0.121^{b}$ & $0.014 \pm 0.014^{b}$ & $0.009 \pm 0.003^{b}$ & $0.277 \pm 0.041^{b}$ \\
\hline & & $30 \mathrm{~min}$ & $0.298 \pm 0.118^{c}$ & $0.020 \pm 0.004^{c}$ & $0.015 \pm 0.003^{c}$ & $0.374 \pm 0.041^{c}$ \\
\hline
\end{tabular}

Values with different letters in each column are significantly different with $p$-value $(<0.05)$

phosphate. Therefore, noodles can contain high level of Al. Levels of $\mathrm{Pb}, \mathrm{Cd}$ and As in noodles were less than those in the previous studies. $\mathrm{Pb}$ and $\mathrm{Cd}$ were found in noodles of $40 \mathrm{~g}$ in the range of 46.8 to $66.8 \mu \mathrm{g}$ and 21.2 to $32.8 \mu \mathrm{g}$, respectively [32]. They were also similar with the levels in raw materials such as flour and sweet potatoes. $\mathrm{Pb}$ of $3.26(\mathrm{LB})$ and $4.00(\mathrm{UB}) \mu \mathrm{g}$ in starchy roots of $40 \mathrm{~g}$ and 0.884 (LB) and 1.580 (UB) $\mu \mathrm{g}$ in cereal products of $40 \mathrm{~g}$ were detected in EU [29]. Cereal products excluding rice based products of $40 \mathrm{~g}$ were containing As of 


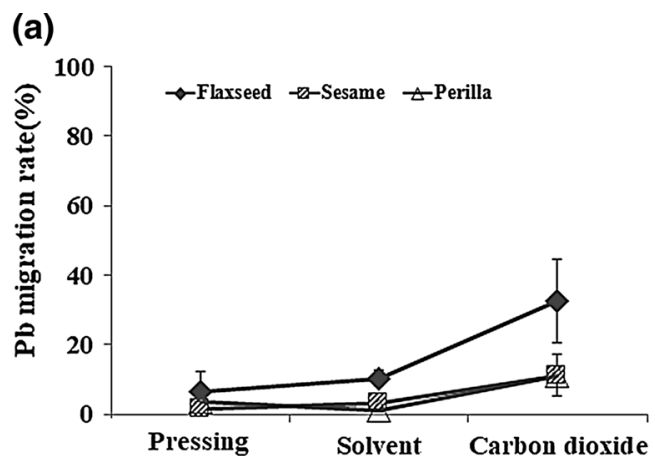

(c)

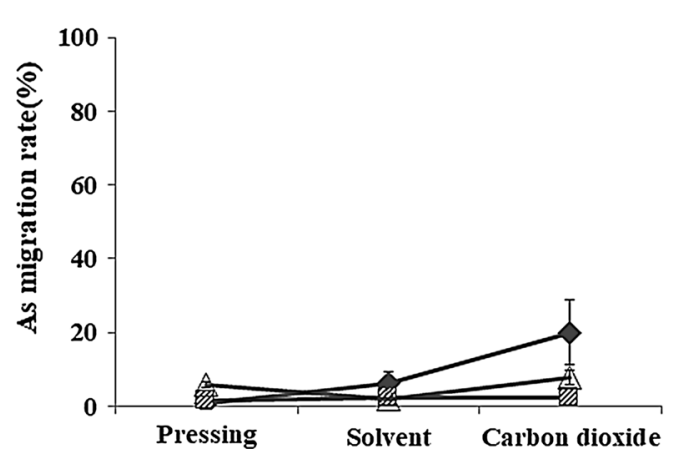

(b)

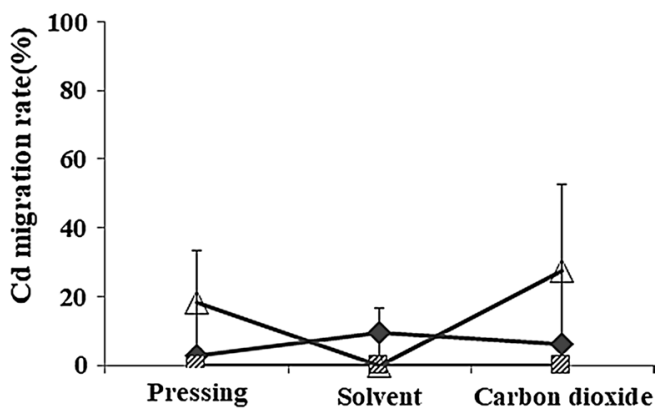

(d)

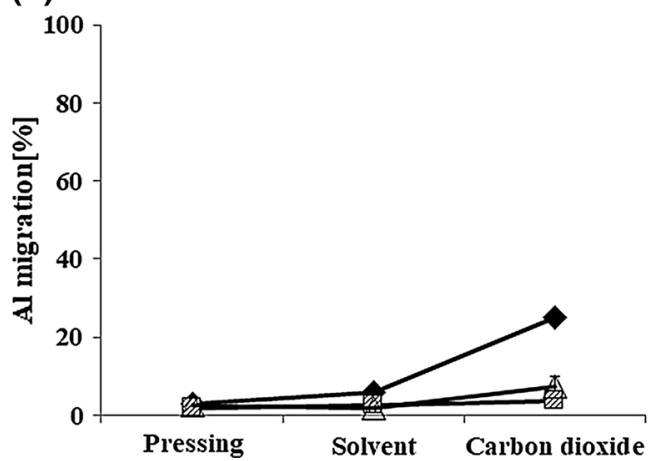

Fig. 2 Migration rates of heavy metals, a lead, b Cadmium, c Arsenic and $\mathbf{d}$ Aluminium during extracting edible oils from different seeds by different processing methods

$0.428(\mathrm{LB})$ and $1.188(\mathrm{UB}) \mu \mathrm{g}$ and starchy roots or potatoes of $40 \mathrm{~g}$ were contaminated by As of 0.124 (LB) and 0.568 (UB) $\mu \mathrm{g}$ in EU [11] and wheat and flour contains $\mathrm{Cd}$ of $1.200 \mu \mathrm{g}$ and other starchy roots excluding potatoes contain Cd of $0.632 \mu \mathrm{g}$ in EU [12]. Stahl showed that the levels of $\mathrm{Al}$ in food were ND to $29.480 \mathrm{mg}$ and flour was contaminated with $\mathrm{Al}$ in the range from 0.040 to $0.760 \mathrm{mg}$ [33].

Heavy metals were significantly decreased $(\mathrm{p}<0.05)$ during boiling noodles for $3 \mathrm{~min}$ (Fig. 3). $\mathrm{Pb}, \mathrm{Cd}$, and $\mathrm{Al}$ in flour noodles were remained by $43.8 \%, 21.4 \%$ and $33.4 \%$, and $\mathrm{Pb}$ and $\mathrm{Al}$ in glass noodles were decreased by $53.8 \%$ and $56.7 \%$ during boiling noodles for $3 \mathrm{~min}$. The levels of heavy metals in noodles were not significantly reduced from 3 to $10 \mathrm{~min}$ other than $\mathrm{Al}$. This is because heavy metals were transferred to water during boiling noodles and most heavy metals were quickly dissolving in water during boiling. We did not study the effects of the amount of heavy metals, noodles and water. Further studies are needed to figure out factors which effect on the solubility of heavy metals. Al content was significantly decreased as boiling time increased. It would be because $\mathrm{Al}$ contents was much higher than other heavy metal contents. It would take more time for Al to dissolve in water rather than $\mathrm{Pb}, \mathrm{Cd}$ and $\mathrm{As}$.
The risk of heavy metals in noodles would be reduced when noodles are consumed after boiling them and removing the water in which noodles cooked. It would be much realistic risk assessment of heavy metals in noodles when considering the migration rates of heavy metals. In previous study, the risk of $\mathrm{Al}$ in instant noodles were of concern with Percentile $95 \%$ of target hazard quotient (THQ) of 1.789 for adult [34]. However, the risk of $\mathrm{Al}$ in instant noodles would be safe with THQ of 0.597 less than 1 when the residual rate of $\mathrm{Al}$ of $33.4 \%$ in flour noodle was considered.

\section{Change of heavy metal contents by infusing teas}

Black teas of $1.2 \mathrm{~g}$ were containing $\mathrm{Pb}$ of $0.657 \pm 0.061 \mu \mathrm{g}$, $\mathrm{Cd}$ of $0.011 \pm 0.001 \mu \mathrm{g}$, As of $0.005 \pm 0.005 \mu \mathrm{g}$ and $\mathrm{Al}$ of $1.039 \pm 0.039 \mathrm{mg}$. And green teas of $1.2 \mathrm{~g}$ were contaminated by $\mathrm{Pb}$ of $0.219 \pm 0.008 \mu \mathrm{g}, \mathrm{Cd}$ of $0.017 \pm 0.002 \mu \mathrm{g}$, As of $0.073 \pm 0.015 \mu \mathrm{g}$ and $\mathrm{Al}$ of $4.694 \pm 0.119 \mathrm{mg}$. Solomon's seal teas of $1.2 \mathrm{~g}$ showed the contaminations of $\mathrm{Pb}$ in $0.474 \pm 0.163 \mu \mathrm{g}, \mathrm{Cd}$ in $0.054 \pm 0.008 \mu \mathrm{g}$, $0.053 \pm 0.009 \mu \mathrm{g}$ and $0.428 \pm 0.025 \mathrm{mg}$. (Table 2). Teas were also contaminated with $\mathrm{Al}$ at most, and $\mathrm{Pb}$ contents were higher than $\mathrm{Cd}$ and As contents. The levels of $\mathrm{Pb}$, $\mathrm{Cd}$ and As in teas were similar with the previous studies. $\mathrm{Al}$ contents are higher than other heavy metals followed 

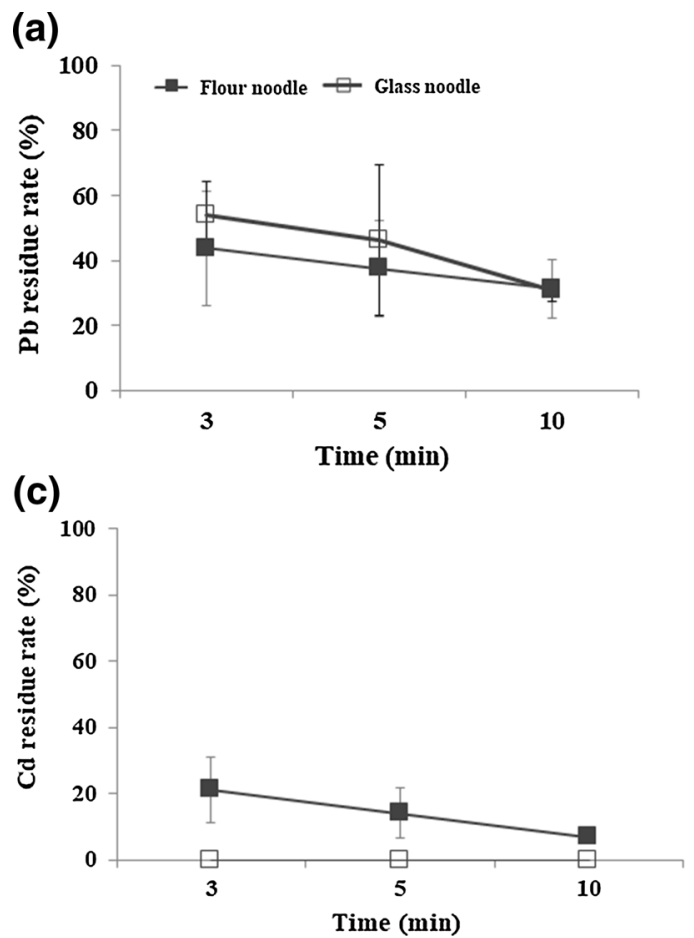

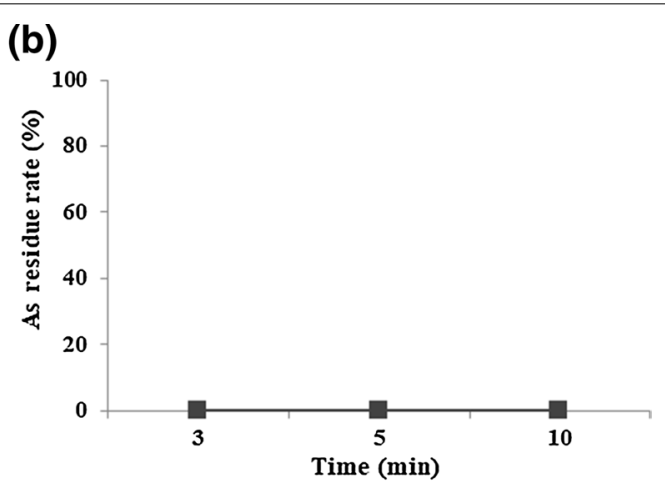

(d)

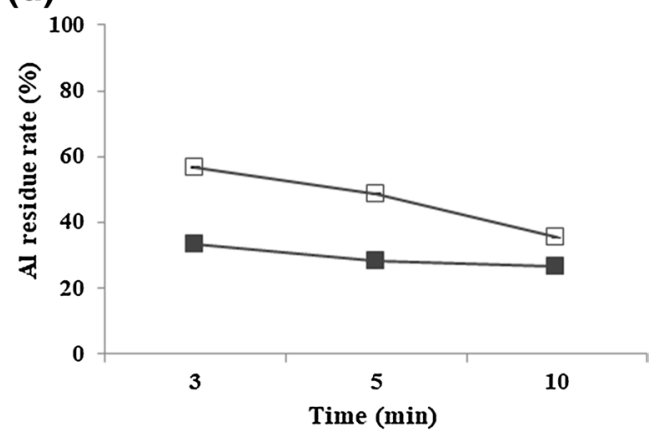

Fig. 3 Migration rates of heavy metals, a lead, $\mathbf{b}$ Cadmium, c Arsenic and $\mathbf{d}$ Aluminium during boiling noodles at different time

by $\mathrm{Pb}$. Karak and Bhagat were reviewed the heavy metal contents in teas. Black teas of $1 \mathrm{~g}$ were contaminated by $\mathrm{Pb}$ in a range between ND to $240.1 \mu \mathrm{g}, \mathrm{Cd}$ of from ND to $1.92 \mu \mathrm{g}$, As of from ND to $4.3 \mu \mathrm{g}$ and $\mathrm{Al}$ of from 0.168 to $2.716 \mathrm{mg}$ [35]. Green teas of $1 \mathrm{~g}$ were contaminated by $\mathrm{Pb}$ from 0.11 to $3.92 \mu \mathrm{g}$, Cd from 0.013 to $0.114 \mu \mathrm{g}$, As from $\mathrm{ND}$ to $1.66 \mu \mathrm{g}$, and $\mathrm{Al}$ from 0.211 to $4.074 \mathrm{mg}$. However, there are no studies to determine heavy metals in Solomon's seal teas.

Heavy metals were significantly decreased in tea infusion after infusing tea for $2 \mathrm{~min}$. $\mathrm{Pb}$ was transferred to tea infusion by $50.2 \%$ in black tea, $21.3 \%$ in green tea and $18.2 \%$ in Solomon's seal tea. Cd of $33.3 \%$ in black tea, $14.3 \%$ in green tea and $6.7 \%$ in Solomon's seal tea was transferred to tea infusion. In case of As, the migration rates were $46.3 \%$ in black tea, $4.9 \%$ in green tea and $4.5 \%$ in Solomon's seal tea. Al were transferred to infusion by $63.9 \%$ in black tea, $30.7 \%$ in green tea and $49.9 \%$ in Solomon's seal tea. The migration of heavy metals into tea infusion is metal dependent and heavy metals contents were increased as the infusion time increased from 2 to 10 and $30 \mathrm{~min}$ (Fig. 4). Pb and Cd were highly transferred to tea infusion with longer infusion time in other study [18]. Especially, black tea showed the highest migration rates and green tea had the lowest migration rates. Black tea were made from green tea by oxidation which is called fermentation procedure. Heavy metals bio-concentrate to metal chelates in plans and metal chelates would be changed by oxidation in black tea. Therefore, heavy metals in black tea would be easily migrated to infusion [36].

When assessing the risk of heavy metals in teas with analysing them, it would be much realistic to consider the migration rates of heavy metals in teas. Nkansah assessed the risk of heavy metal in black tea including As [37]. The average carcinogenic risk of As through drinking black tea was $1.48 \times 10^{-4}$ and it was greater than the acceptable limits of $10^{-6}$. However, this research was analysing black tea leaves and did not consider migration rate of As during infusing black tea. Therefore, the carcinogenic risk of As would be decreased to $6.83 \times 10^{-5}$ when the migration rate of As in black tea of $46.2 \%$ evaluated in this study were calculated. The risk of As of Puerh tea was assessed in Puer, China. The $95^{\text {th }}$ percentile carcinogenic risk were $1.07 \times 10^{-4}$ and $1.19 \times 10^{-4}$ for male, and they were of concern exceeding the acceptable level of $10^{-4}$ [38]. However, the carcinogenic risks would be reduced to 0 or $4.94 \times 10^{-5}$ for all and 0 or $5.50 \times 10^{-5}$ for male with migration rate of As in green tea or black tea. Therefore, the 95th percentile carcinogenic risk would not be concern. 
(a)

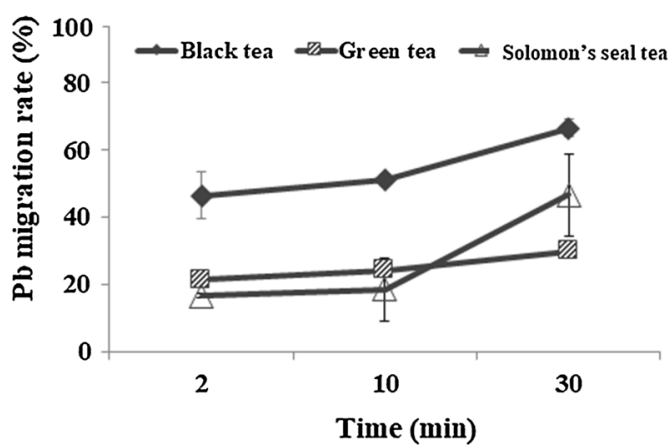

(c)

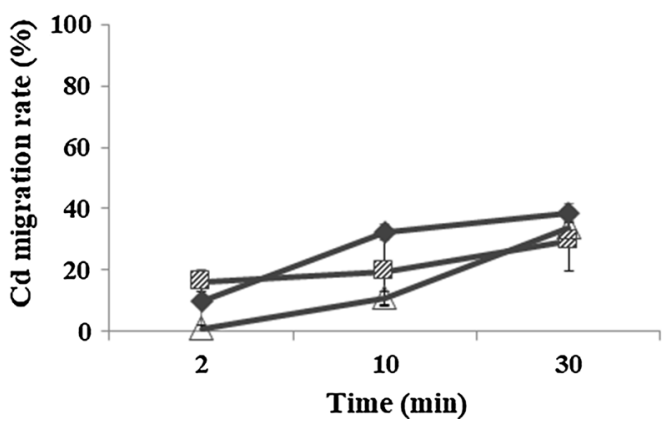

(b)

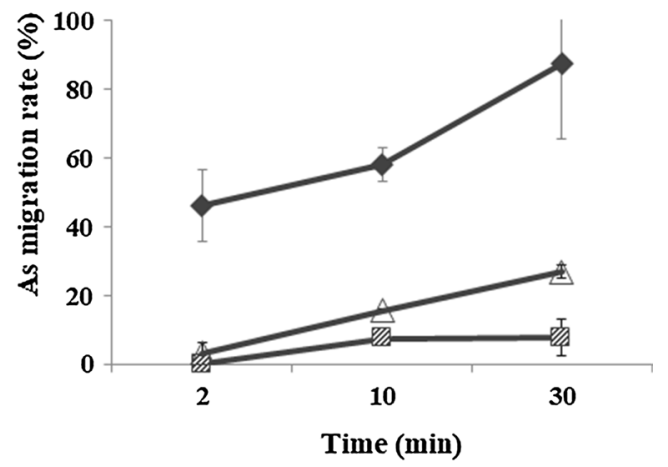

(d)

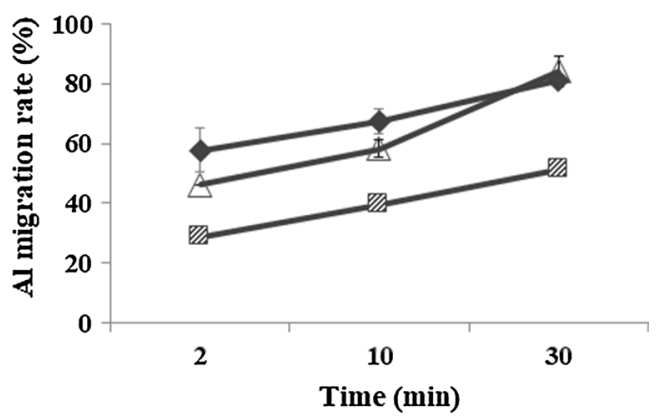

Fig. 4 Migration rates of heavy metals, a lead, b Cadmium, c Arsenic and $\mathbf{d}$ Aluminium during infusing teas at different time

\section{Acknowledgements}

This research was supported by a grant (18161MFDS020) from the Ministry of Food and Drug Safety in 2018.

\section{Authors' contributions}

JGL validated analytical method and analysed samples and JYH and HEL statistically analysed data. THK interpreted effects of food processing on contents of PAHs. JDC operated the analytical instruments and analyse data. GJG organized this study and manuscript. All authors read and approved the final manuscript.

\section{Funding}

This research was supported by a grant (18161MFDS020) from Ministry of Food and Drug.

\section{Availability of data and materials}

All data analysed during this study are included in this published article.

\section{Competing interests}

The authors declare that they have no competing interests.

Received: 8 September 2019 Accepted: 16 October 2019

Published online: 04 November 2019

\section{References}

1. Tian D, Zhu F, Yan W, Fang X, Xiang W, Deng X, Wang G, Peng C (2009) Heavy metal accumulation by panicled goldenrain tree (Koelreuteria Paniculata) and common elaeocarpus (Elaeocarpus decipens) in abandoned mine soils in southern China. J Environ Sci 21:340-345

2. Onakpa MM, Njan AA, Kalu OC (2018) A review of heavy metal contamination of food crops in Nigeria. Ann Glob Health 84(3):488-494
3. Peralta-Videa JR, Lopez ML, Narayan M, Saupe G, Gardea-Torresdey G (2009) The biochemistry of environmental heavy metal uptake by plants: implications for the food chain. Int J Biochem Cell Biol 41:1665-1677

4. Das SK, Grewal AS, Banerjee M (2011) A brief review: heavy metals and their analysis. Int J Pharm Sci Rev Res 11(1):13-18

5. Järup L (2003) Hazards of heavy metal contamination. Br Med Bull 68:167-182

6. World Health Organization (2001) Arsenic and Arsenic compounds. Environmental Health Criteria. World Health Organization, Geneva, p 224

7. Järup L, Berglund M, Elinder CG, Nordberg G, Vahter M (1998) Health effects of cadmium exposure- a reviewof the literature and a risk estimate. Scand J Work Environ Health 24(1):1-51

8. Krewski D, Yokel RA, Nieboer E, Borchelt D, Cohen J, Harry J, Kacew S, Lindsay J, Mahfouz AM, Rondeau V (2007) Human health risk assessment for aluminium, aluminium oxide, and aluminium hydroxide. J Toxicol Environ Health Part B 10:1-269

9. Flaten TP (2001) Aluminium as a risk factor in Alzheimer's disease, with emphasis on drinking water. Brain Res Bull 55(2):187-196

10. EFSA (European Food Safety Agency) (2008) Scientific opinion of the panel on food additives, processing aids and food contact materials on a request from European commission on safety of aluminium from dietary intake. EFSA J 754:1-34

11. EFSA (European Food Safety Agency) (2009) EFSA panel on contaminants in the food chain (CONTAM); Scientific opinion on arsenic in food. EFSA J 7(10):1351

12. EFSA (European Food Safety Agency) (2009) Scientific opinion of the panel on contaminants in the food chain on a request from the European commission on cadmium in food. EFSA J 980:1-139

13. Chizzola R (1998) Uptake and partitioning of cadmium in sunflowers, chmomile and St. Joh's wort. Zeischrigt fur Arznei Gewurpzflanzen. 3:91-95

14. Simon L (1998) Cadmium accumulation and distribution in sunflower plnat. J Plant Nutr 21:341-352 
15. Eckhardt H, Khanel SK (1999) Suitability of Bangkok sewage and nightsoil sludges for agricultural use with emphasis on potentially toxic elements. J Environ Sci Health Part A 34:2007-2021

16. Anelova V, Ivanova R, Ivanov K (2005) Heavy metal accumulation and distribution in oil crops. Commun Soil Sci Plant Anal 35(17-18):2551-2566

17. Santos LMG, Duboc P, Goncalves JM, Jacob SC (2015) Determination of arsenic, cadmium and lead concentration in teas, commercialized in Rio De Janeiro, Brazil, and their transfer to tea infusion. Biol Chem Res 2015:179-186

18. Subbiah S, Oates RP, Dhanakodi K, Annamalai SK, Muraleedharan N (2017) Impact of Brewing time on heavy metal leaching in black tea from South India. Austin Environ Sci 2(2):1-4

19. Korea Centers for Disease Control and Prevention (CDC) (2010) Guideline for the evaluation of the fourth Korea national health and nutrition examination survey. Korea Centers for Disease Control and Prevention, Osong

20. Moraghan JT (1993) Accumulation of cadmium and selected elements in flaxseed grown on a calcareous soil. Plant Soil 150(1):61-68

21. Pradhan RC, Meda V, Rout PK, Naik S, Dalai AK (2010) Supercritical $\mathrm{CO}_{2}$ extraction of fatty oil from flaxseed and comparison with screw press expression and solvent extraction processes. J Food Eng 98:393-397

22. Willems P, Kuipers NJM, De Haan AB (2008) Hydraulic pressing of oilseeds: experimental determination and modelling of yield and pressing rates. J Food Eng 89:8-16

23. Venter MJ, Kuipers NJM, De Haan AB (2007) Modelling and experimental evaluation of high-pressure expression of cocoa nibs. J Food Eng 80(4):1157-1170

24. Rout PK, Naik SN, Rao YR (2008) Subcritical $\mathrm{CO}_{2}$ extraction of floral fragrance from Quisqualis indic. J Supercirit Fluids 45:200-205

25. Taverniers L, Loose MD, Bockstaele EV (2004) Trends in quality in the anaIytical laboratory. II. Analytical method validation and quality assurance. Trends Anal Chem 23:535-552

26. Oomah BD, Berekoff B, Li-Chan ECY, Mazza G, Kenaschuk EO, Duguid SD (2007) Cadmium-binding protein components of flaxseed: influence of cultivar and location. Food Chem 100:318-325

27. Sinha B, Bhattacharyya K, Giri PK, Sarkar S (2010) Arsenic contamination in sesame and possible mitigation through organic interventions in the lower Gangetic Plain of West Bengal, India. J Sci Food Agric 91:2762-2767
28. Zhu F, Fan W, Wang X, Qu L, Yao S (2011) Health risk assessment of eight heavy metals in nine varieties of edible vegetable oils consumed in China. Food Chem Toxicol 49:3081-3085

29. EFSA (European Food Safety Agency) (2010) EFSA panel on contaminants in the food chain (CONTAM); Scientific opinion of lead in food. EFSA J 8(4):1570

30. Roussel C, Néel C, Bril H (2000) Minerals controlling arsenic and lead solubility in an abandoned gold mine tailings. Sci Total Environ 263:209-219

31. Gómez AM, López CP, Ossa EM (1996) Recovery of grape seed oil by liquid and supercritical carbon dioxide extraction: a comparison with conventional solvent extraction. Chem Eng J 61:227-231

32. Jothi JS, Uddin MB (2014) Detection of heavy metals in some commercial brands of noodles. Eur Acad Res 2(8):10667-10679

33. Stahl T, Taschan H, Brunn H (2011) Aluminium content of selected foods and food products. Environ Sci Eur 23(37):1-11

34. Tajdar-oranj B, Shariatifar N, Alimohammadi M, Peivasteh-roudsari L, Khaniki GJ, Fakhri Y, Khaneghah AM (2018) The concentration of heavy metals in noodle samples from Iran's market: probabilistic health risk assessment. Environ Sci Pollut Res 25(31):30928-30937

35. KarakT, Bhagat RM (2010) Trace elements in tea leaves, made tea and tea infusion: a review. Food Res Int 43:2234-2252

36. Raskin I, Kumar PBAN, SI Dushenkov, Salt DE (1994) Bioconcentration of heavy metals by plants. Curr Opin Biotechnol 5:285-290

37. Nkansah MA, Opoku F, Ackumey AA (2016) Risk assessment of mineral and heavy metal content of selected tea products from the Ghanaian market. Enviorn Monit Assess 188(332):2-11

38. Cao H, Qjao L, Zhang H, Chen J (2010) Exposure and risk assessment for aluminium and heavy metals in Puerh tea. Sci Total Environ 408:2777-2784

\section{Publisher's Note}

Springer Nature remains neutral with regard to jurisdictional claims in published maps and institutional affiliations.

\section{Submit your manuscript to a SpringerOpen ${ }^{\circ}$ journal and benefit from:}

- Convenient online submission

- Rigorous peer review

- Open access: articles freely available online

- High visibility within the field

- Retaining the copyright to your article

Submit your next manuscript at springeropen.com 